\title{
Preparation and Characterization of Some Hyperbranched Polyesteramides/Montmorillonite Nanocomposites
}

\author{
Amal Amin and Moshera Samy \\ Polymers and Pigments Department, National Research Center, Dokki, Giza, Egypt \\ Correspondence should be addressed to Amal Amin; aamin_07@yahoo.com
}

Received 3 February 2013; Revised 29 April 2013; Accepted 20 May 2013

Academic Editor: Yan Bao

Copyright ( 2013 A. Amin and M. Samy. This is an open access article distributed under the Creative Commons Attribution License, which permits unrestricted use, distribution, and reproduction in any medium, provided the original work is properly cited.

Different polyesteramides hyperbranched polymers (HPEA1-6)/montomorillonite clay (MMT) nanocomposites were prepared with three different loading contents of clay $(4,10$, and $15 \mathrm{wt} \%)$. The obtained nanocomposites were characterized via XRD, thermal analyses, and TEM. Generally, intercalation behavior was observed. The hyperbranched polyesteramides (HPEA1-6) were originally prepared by the bulky reaction between maleic anhydride (MAn), succinic anhydride (ScAn), and phthalic anhydride (PhAn) with either diethanolamine (DEA) or diisopropanolamine (DiPA). The resulting hyperbranched polyesteramides (HPEA1-6) were characterized by GPC, IR, ${ }^{1} \mathrm{H}-\mathrm{NMR}$, TGA, and DSC.

\section{Introduction}

Recently, polymer/clay nanocomposites have been considered as rising area of research from both scientific and industrial perspectives where they result from the interaction between the organic polymer phase and the inorganic clay phase. Therefore, polymer/clay nanocomposites combine both the properties of inorganic phase such as rigidity, high stability, and the properties of organic phase such as flexibility, dielectric, ductility, and processability [14]. Layered silicates such as montmorillonite are the most versatile member of the nanofillers used in manufacturing polymer/clay nanocomposites. The nanoparticles improve the polymer performance over conventional fillers with a smaller loading content [5]. The advantages of nanocomposites include enhanced mechanical properties such as elastic modulus [6] and tensile strength $[7,8]$.

Additional enhancements are expected in coefficient of linear thermal expansion, heat distortion temperature, flammability resistance, ablation performance, gas barrier properties, and others [9-12]. Generally, polymer/clay nanocomposites have been widely used in many fields, such as automobile and tire industries, construction fields, food packaging, electrical fields, antimicrobial agents, and other potential applications [13-17]. Several polymers are involved in producing such nanocomposites as vinyl polymers [18, 19], condensation polymers $[20,21]$, polyolefins $[22,23]$, and others $[24,25]$. Hyperbranched polymers have been lately used in such nanocomposites due to their brilliant physical and chemical properties to obtain nanocomposites with excellent properties that can be invested in different applications [26, 27]. Hyperbranched polymers belong to the dendritic polymers; however, they are prepared via several easy preparative methods in one-pot reaction which is considered as merit over the dendrimers themselves especially in the industry where dendrimers are labor-intensive materials. Hyperbranched polymers with numerous different functional groups can be obtained due to the easy-end groups' modification, for example, esters, carboxylic acids, and tertiary amines [28]. The hyperbranched polyesteramides represent important category of the functional and widely applicable hyperbranched polymers which were firstly developed in an industrial viable route by van Bentherm and others [29]. Thereby, the produced hyperbranched polymers had improved flow and air-drying properties for use in combination with alkyd resins. Those products were tested for plastics-additives applications [30]. Generally, hyperbranched polyesteramides (HBPAs) were synthesized by the bulk polycondensation of a trifunctional dialkanolamine (DAA) as bB2 monomer, where b and $\mathrm{B} 2$ represent the 
secondary amine and the two alcohol functional groups, respectively, and a difunctional cyclic anhydride (CAn), as an Aa monomer, where Aa represents the anhydride functional group [31]. The hyperbranched polyesteramides-because of the special shape and the large number of end groups of highly branched structures-have several applications in coatings, surface modifiers, biomedical applications, and others [32, 33]. Consequently, in the current publication, members of hyperbranched polyesteramides were chosen to be involved in forming some nanocomposites with montomorillonite clay to be used in the future in our research group in several applications specifically in the biomedical ones.

\section{Experimental}

2.1. Chemicals. Maleic anhydride (MAn) (98\%), succinic anhydride (ScAn) (98\%), and diisopropanolamine (DiPA) (98\%) were provided by Fluka, Germany. Phthalic anhydride $\left(\mathrm{PhA}_{n}\right)(99.98 \%)$ was purchased from Arab lab, Dubai, UAE. Diethanolamine (DEA) (99\%) was from analytical Rasayan, India. Montmorillonite (MMT) clay was provided by Southern clay products, TA, USA.

2.2. Instrumentation. Gel permeation chromatography (GPC) was used to determine number-average molecular weight $\left(\bar{M}_{n}\right)$ and polydispersity $\left(D=\bar{M}_{w} / \bar{M}_{n}\right)$ of the polymers by using Agilent-1100 GPC technologies with refractive index detector where polystyrene (PS) and N, $\mathrm{N}^{\prime}$-dimethyl formamide (DMF) were used as standard and eluent, respectively. Infrared spectra (IR) were recorded via Pye-Unicum SP-1100 in the range of $400-4000 \mathrm{~cm}^{-1}$ using $\mathrm{KBr}$ pellets.

Nuclear magnetic resonance $\left({ }^{1} \mathrm{HNMR}\right)$ was measured via Jeol JNM-EX $270 \mathrm{MHZ}$ using tetramethylsilane (TMS) as internal standard and DMSO- $\mathrm{d}_{6}$ as the deuterated solvent.

Thermogravimetric analysis (TGA) was performed on TGA Q $5000 \mathrm{TA}$ instrument, in the range from 40 to $750^{\circ} \mathrm{C}$ with heating rate $10 \mathrm{~K} / \mathrm{min}$ under nitrogen. Differential scanning calorimetry (DSC) was conducted to determine the glass transition temperatures $\left(T_{g}\right)$ by using differential scanning calorimeter Q $1000 \mathrm{TA}$ from $-80^{\circ} \mathrm{C}$ to $150^{\circ} \mathrm{C}$ with scanning rate of $20 \mathrm{~K} /$ minutes under nitrogen. The morphology of the nanocomposites was investigated via transmission electron microscopy (TEM) JEOL-JEM-1230 at $100 \mathrm{KV}$ by drop casting the suspended sample onto carbon-coated copper grids, followed by evaporation of the solvent in air.

2.3. General Preparative Method of Anhydride-Based Hyperbranched Polyesteramides [28, 33]. The hyperbranched polyesteramides $\left(\mathrm{HPEA}_{1-6}\right)$ were prepared by introducing $(0.115 \mathrm{~mol})$ of DiPA or DEA into three-necked flask equipped with a mechanical stirrer, thermometer, and a vacuum pump and placed at thermostated oil bath. Then, $0.10 \mathrm{~mol}$ of anhydride was added to the flask. The reaction mixture was gradually heated to $70^{\circ} \mathrm{C}$, with continuous stirring, and then more slowly to $170^{\circ} \mathrm{C}$. Vacuum was applied during heating to remove the condensates. The formed hyperbranched polymer was washed with acetone, filtered, and dried at $50^{\circ} \mathrm{C}$ for 24 hours.

2.4. Preparation of Polymer/Clay Nanocomposites. For synthesis of polymer/clay nanocomposites, $0.45,0.3$, and $0.12 \mathrm{gm}$ of untreated MMT corresponding to three percent of clay (e.g., 15, 10, and $4 \mathrm{wt} \%$, resp.) were used individually with the equivalent amounts of $9.35 \times 10^{-5}$ mol of HPEA $_{1-6}$. The used amount of MMT was dispersed in $60 \mathrm{~mL}$ distilled $\mathrm{H}_{2} \mathrm{O}$ for $24 \mathrm{~h}$ at $60^{\circ} \mathrm{C}$. The hyperbranched polymer was dissolved separately in $40 \mathrm{~mL}$ distilled $\mathrm{H}_{2} \mathrm{O}$ for $3 \mathrm{~h}$ at the same temperature. Then, the hyperbranched polymer solution was added to the dispersed clay with stirring for $24 \mathrm{~h}$ at $60^{\circ} \mathrm{C}$. The formed precipitate was filtered and dried. The resulting nanocomposites were characterized by XRD, TGA, DSC, and TEM.

\section{Results \& Discussion}

Polymer/clay nanocomposites are good example on organic/inorganic hybrids gathering the advantages of both sides which are widely invested in numerous applications [13-17]. Hyperbranched polymers represent relatively new polymeric member in this category of composite materials [26, 27]. Accordingly, herein, hyperbranched polyesteramides $\left(\mathrm{HPEA}_{1-6}\right.$, Figure 1) were subjected to form nanocomposites with clay to be progressively applied in current work at our laboratories that will be published later.

3.1. Characterization of the Hyperbranched Polymers $H P E A_{1-6}$. HPEA $_{1-6}$ polymers were prepared via one-pot reaction between anhydrides $(\mathrm{Aa})$ and dialkanolamines $\left(\mathrm{bB}_{2}\right)$ $[28,33]$. Three different anhydrides were used such as maleic anhydride, succinic anhydride, and phthalic anhydride. Diethanolamine (DEA) and diisopropanolamine (DiPA) were involved in such condensation preparative reactions. $\mathrm{HPEA}_{1,3,5}$ resulted from the reaction of maleic, succinic and phthalic anhydrides, respectively, with diethanolamine (DEA). HPEA $_{2,4,6}$ resulted from similar reaction of the same anhydrides with diisopropanolamine (DiPA). The prepared parent hyperbranched polymers $\left(\mathrm{HPEA}_{1-6}\right)$ were characterized via GPC, IR, and ${ }^{1} \mathrm{HNMR}$ to confirm their structures [34-36]. Accordingly, GPC of HPEA $_{1-6}$ recorded $\bar{M}_{n}$ and $D$ values for each hyperbranched polymer. $\bar{M}_{n}$ and PDI values were found to be $2000 \mathrm{~g} / \mathrm{mol} \& 3.53$ for $\mathrm{HPEA}_{1}, 3500 \mathrm{~g} / \mathrm{mol} \& 2.54$ for $\mathrm{HPEA}_{2}, 1400 \mathrm{~g} / \mathrm{mol} \& 1.43$ for $\mathrm{HPEA}_{3}, 1800 \mathrm{~g} / \mathrm{mol} \& 1.56$ for $\mathrm{HEA}_{4}, 2100 \mathrm{~g} / \mathrm{mol} \& 1.27$ for $\mathrm{HPEA}_{5}$, and $2400 \mathrm{~g} / \mathrm{mol} \& 1.64$ for $\mathrm{HPEA}_{6}$. Further evidence on formation of the former $\mathrm{HPEA}_{1-6}$ was provided via IR where IR spectra of HPEA $_{1-6}$ showed several supportive bands for the structures. Thereby, IR of HPEA 1 and $\mathrm{HPEA}_{2}$ $\left(\mathrm{KBr}, \nu \mathrm{cm}^{-1}\right): 3432-3421(\mathrm{O}-\mathrm{H}), 1643-1641 \quad(\nu \mathrm{C}=\mathrm{O}$ in amide groups), $1734-1731$ ( $\nu \mathrm{C}=\mathrm{O}$ for $\alpha$-unsaturated carbonyl of ester groups), two bands at 2978-2940 and 2934-2876 (C-H stretching), bands at 1494-1487 \& 1451-1450 $\left(\mathrm{CH}_{2}\right.$ bending), 1377 ( $\mathrm{CH}_{3}$ bending), 943-856 and 1066-1050 (=CH bending). The bands at 1129-1125, 1184-1175, and 12761269 were ascribed to $\mathrm{C}-\mathrm{O}$ and $\mathrm{C}-\mathrm{N}$ stretching. IR of $\mathrm{HPEA}_{3}$ 
<smiles>[R]C(O)CN(CC([R])O)C(=O)CCCC(=O)OC([R])CN(CC([R])OC(=O)CCC(=O)N(CC([R])O)CC([R])OC(=O)CCC(=O)N(CC([R])O)CC([R])O)C(=O)CCC(=O)N(CC([R])OC(=O)CCCC(=O)N(CC([R])O)CC([R])O)CC([R])OC(=O)CCC(=O)N1CC([R])OC([R])C1</smiles>

Where $\mathrm{HPEA}_{1,2}: \mathrm{R}=\mathrm{H}, \mathrm{CH}_{3}, \mathrm{C}=$ maleic anhydride,

$\mathrm{HPEA}_{3,4}: \mathrm{R}=\mathrm{H}, \mathrm{CH}_{3}, \mathrm{C}=$ succinic anhydride,

$\mathrm{HPEA}_{5,6}: \mathrm{R}=\mathrm{H}, \mathrm{CH}_{3}, \mathrm{C}=$ phthalic anhydride

FIGURE 1: Representation of molecular structure of hyperbranched polyesteramides.

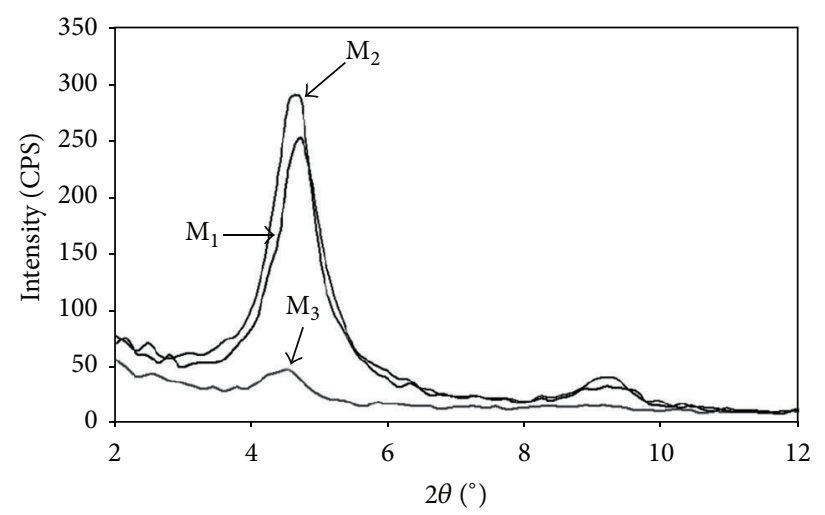

(a)

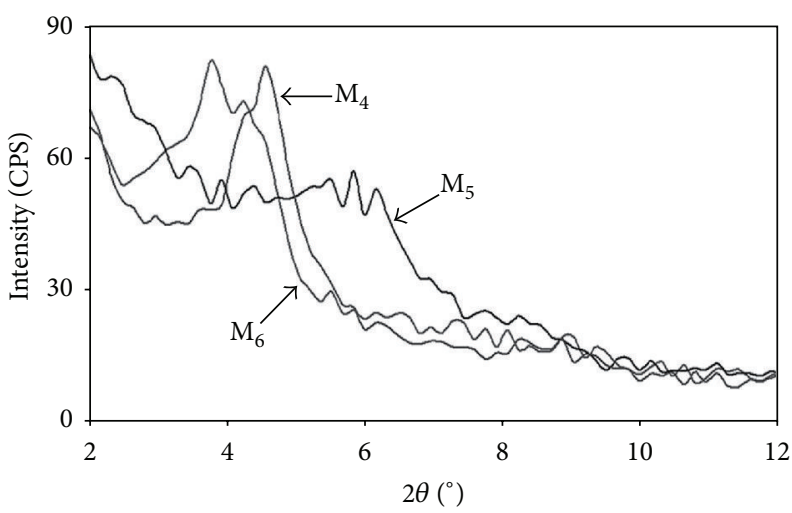

(b)

Figure 2: XRD of $\mathrm{M}_{1}$ to $\mathrm{M}_{6}$.

and $\mathrm{HPEA}_{4}\left(\mathrm{KBr}, \nu \mathrm{cm}^{-1}\right): 3441-3396(\nu \mathrm{O}-\mathrm{H}), 1624-1622$ ( $\nu \mathrm{C}=\mathrm{O}$ in amide groups), $1727-1724(\nu \mathrm{C}=\mathrm{O}$ in ester groups), 2979-2953 (C-H stretching), 1416 ( $\mathrm{CH}_{2}$ bending), 1260-1234 (C-O stretching), and 1074-1064 (C-N stretching). IR of $\mathrm{HPEA}_{5}$ and $\mathrm{HPEA}_{6}\left(\mathrm{KBr}, \nu \mathrm{cm}^{-1}\right): 3401-3392(\nu \mathrm{O}-\mathrm{H})$, $1623-1612(\nu \mathrm{C}=\mathrm{O}$ in amide groups), $1721-1720(\nu \mathrm{C}=\mathrm{O}$ in ester groups), 2976-2955 (C-H stretching), $1430-1432\left(\mathrm{CH}_{2}\right.$ bending), 1377 ( $\mathrm{CH}_{3}$ bending), 1276-1269 (C-O stretching), and 1065-1064 (C-N stretching). Lastly, ${ }^{1} \mathrm{HNMR}$ of the previously prepared hyperbranched polymers $\left(\mathrm{HPEA}_{1-6}\right)$ was carried out to confirm the polymer structures. ${ }^{1} \mathrm{H}-\mathrm{NMR}$ for $\operatorname{HPEA}_{1}\left(\mathrm{DMSO}-\mathrm{d}_{6}\right)$, the chemical shifts $(\delta, \mathrm{ppm})$ : 2.9-3.29 $\left(\mathrm{O}=\mathrm{CN}-\mathrm{CH}_{2}\right), 3.39-4.19\left(\mathrm{O}=\mathrm{CO}-\mathrm{CH}_{2}\right), 5.78-6.31$ $(\mathrm{CH}=)$, and $6.4(\mathrm{OH}) \cdot{ }^{1} \mathrm{H}-\mathrm{NMR}$ for $\mathrm{HPEA}_{2}\left(\mathrm{DMSO}^{\left.-\mathrm{d}_{6}\right)}\right), \delta$ (ppm): 1.03-1.11 $\left(\mathrm{CH}_{3}\right), 2.6-3.32\left(\mathrm{CH}_{2}\right), 3.88-4.47(\mathrm{CH}), 5.1$ $(\mathrm{OH})$, and $6.02-6.8(\mathrm{CH}=)$.

${ }^{1} \mathrm{H}-\mathrm{NMR}$ for $\mathrm{HPEA}_{3}$ (DMSO-d $\left.{ }_{6}\right), \delta$ (ppm): $3.59-$ $4.08\left(\underline{\mathrm{C}}_{2}-\mathrm{N}-\mathrm{C}=\mathrm{O}\right),\left(\underline{\mathrm{CH}}_{2}-\mathrm{O}-\mathrm{C}=\mathrm{O}\right)$ and $\left(-\underline{\mathrm{CH}}_{2} \mathrm{OH}\right), 4.2$ 


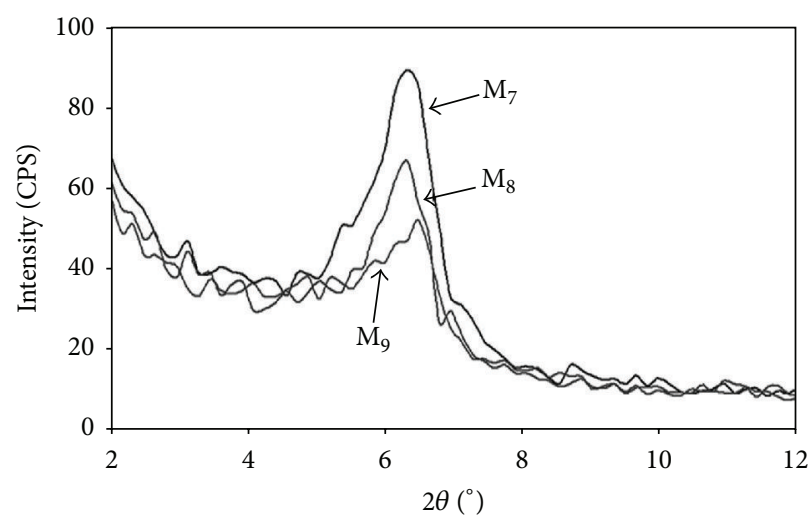

(a)

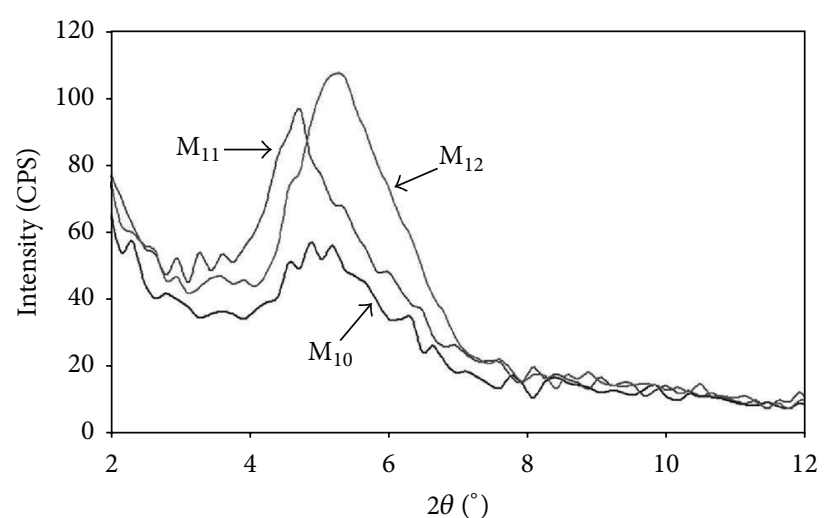

(b)

Figure 3: XRD of $\mathrm{M}_{7}$ to $\mathrm{M}_{12}$.

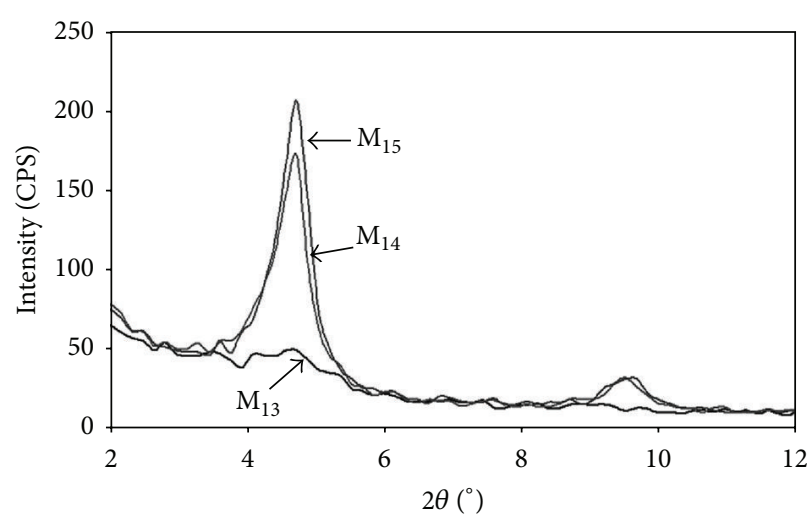

(a)

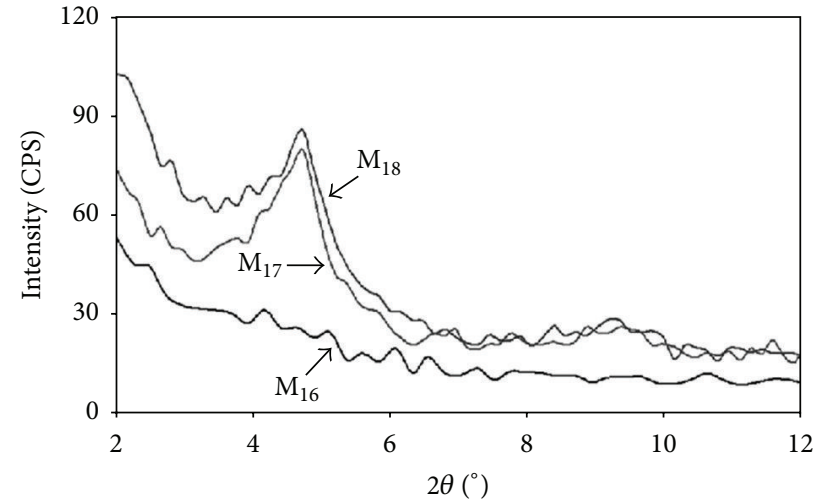

(b)

FIgURE 4: XRD of $\mathrm{M}_{13}$ to $\mathrm{M}_{18}$.

$(\mathrm{OH}) .{ }^{1} \mathrm{H}-\mathrm{NMR}$ for $\mathrm{HPEA}_{4}$ (DMSO-d 6 ), $\delta$ (ppm): 0.95$1.14\left(\mathrm{CH}_{3}\right), 2.26-2.37\left(\mathrm{CH}_{2} \mathrm{CON}\right), 2.6-2.9\left(\mathrm{CH}_{2} \mathrm{COO}\right), 3.26-$ $3.57\left(-\mathrm{CH}_{2} \mathrm{NCO}\right), 3.6(\mathrm{CH})$ and $5.01(\mathrm{OH}) .{ }^{1} \mathrm{H}-\mathrm{NMR}$ for $\mathrm{HPEA}_{5}\left(\mathrm{DMSO}-\mathrm{d}_{6}\right), \delta(\mathrm{ppm}): 2.97-3.38\left(\mathrm{O}=\mathrm{CN}-\mathrm{CH}_{2}\right), 3.62-$ $3.90\left(\mathrm{O}=\mathrm{CO}-\mathrm{CH}_{2}\right), 4.48(\mathrm{OH}), 7.15-8.17(\mathrm{ph}) .{ }^{1} \mathrm{H}-\mathrm{NMR}$ for HPEA $_{6}\left(\right.$ DMSO- $\left._{6}\right), \delta$ (ppm): 0.78-1.31 $\left(\mathrm{CH}_{3}\right), 2.73-3.02$ $\left(\mathrm{C}_{2}\right), 3.56(\underline{\mathrm{C}}), 5.12-5.43(\mathrm{O} \underline{\mathrm{H}})$ and $7.24-8.16(\mathrm{ph})$.

3.2. Hyperbranched Polymers/MMT Nanocomposites. $\mathrm{HPEA}_{1-6}$ formed nanocomposites with untreated MMT depending on the high degree of functionality of the parent hyperbranched polymers. Such kind of functional polymers needs no further modification of clay. Three percent of clay $(4 \%, 10 \%$, and $15 \%)$ was tested in forming such hyperbranched polymers/clay nanocomposites to determine the proper percent for further applications for the expected nanocomposites. The samples $M_{1-3}, M_{4-6}, M_{7-9}$, $\mathrm{M}_{10-12}, \mathrm{M}_{13-15}$, and $\mathrm{M}_{16-18}$ were referred to HPEA $\mathrm{A}_{1}, \mathrm{HPEA}_{2}$, $\mathrm{HPEA}_{3}, \mathrm{HPEA}_{4}, \mathrm{HPEA}_{5}$, and HPEA 6 , respectively (Table 1). The resulting nanocomposites were characterized by XRD where the presence of hyperbranched polymers generally widened the d-spacing inside the internal gallery of clay as seen in Table 1 and (Figures 2, 3, and 4) causing intercalation morphology of the expected nanocomposites. However, the best situation of inclusion of polymers through the clay platelets was observed with respect to $M_{1}, M_{4}, M_{7}, M_{10}, M_{13}$, and $\mathrm{M}_{16}$ in case of lower clay loading contents (4\%) where the highest $\mathrm{d}$-spacing values were recorded at low intensity values more than that in case of the other samples with percent $(10 \%$ or $15 \%)$. Thereby, the d-spacing increased from $1.226 \mathrm{~nm}$ for pristine MMT (33) to 1.935, 2.143, 1.384, 1.856, and $1.865 \mathrm{~nm}$ for $\mathrm{HPEA}_{1-5}$ samples at $4 \%$ clay contents. Also, exfoliation behavior was recorded in case of $\mathrm{HPEA}_{6}$ at the same percent of clay. That behavior was attributed to the high degree of functionalities and hence bulkiness of these polymers which led to the relative destruction of the clay ordering.

The hyperbranched polymers/MMT nanocomposites formed at $4 \%$ clay (i.e., $\mathrm{M}_{1}, \mathrm{M}_{4}, \mathrm{M}_{7}, \mathrm{M}_{10}, \mathrm{M}_{13}$, and $\mathrm{M}_{16}$ ) were further analyzed and characterized via TGA and DSC. For complete comparison, thermal behavior of the parent hyperbranched polymers $\left(\mathrm{HPEA}_{1-6}\right)$ was also studied via TGA and DSC. TG thermograms of $\mathrm{M}_{1}, \mathrm{M}_{4}, \mathrm{M}_{7}, \mathrm{M}_{10}, \mathrm{M}_{13}$, and $M_{16}$ samples are indicated with respect to their parent hyperbranched polymers as in Figures 5-7 [34-36].

Firstly, with respect to $M_{1}, M_{4}$, and their pristine hyperbranched $\mathrm{HPEA}_{1,2}$ polymers (Figure 5), it was observed that only $21.35 \%$ and $17.4 \%$ weight loss was recorded for 


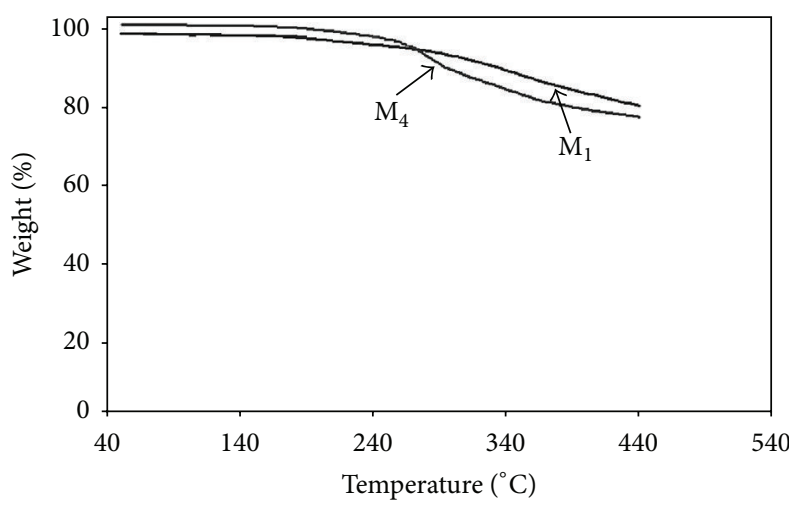

(a)

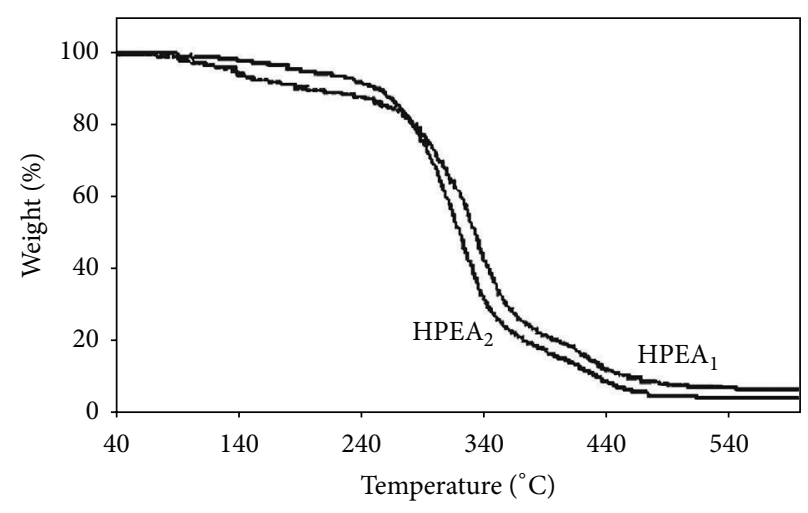

(b)

Figure 5: TGA of $\mathrm{M}_{1}, \mathrm{M}_{4}$, HPEA 1 , and $\mathrm{HPEA}_{2}$.

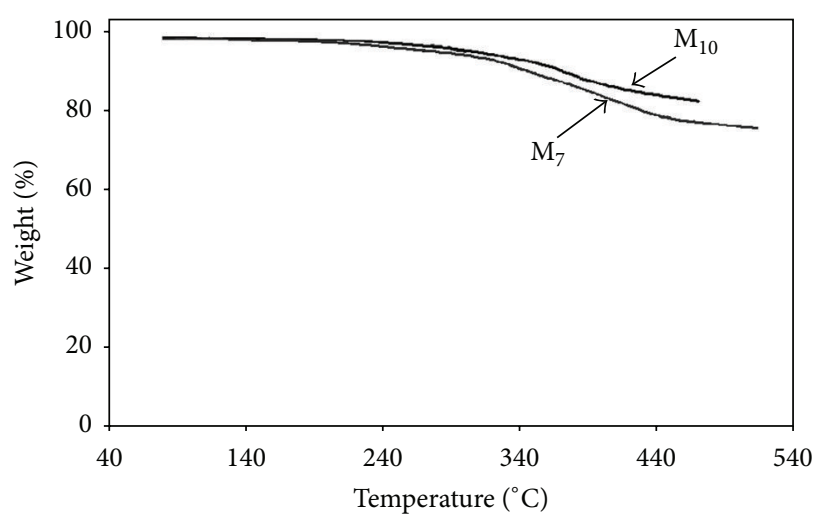

(a)

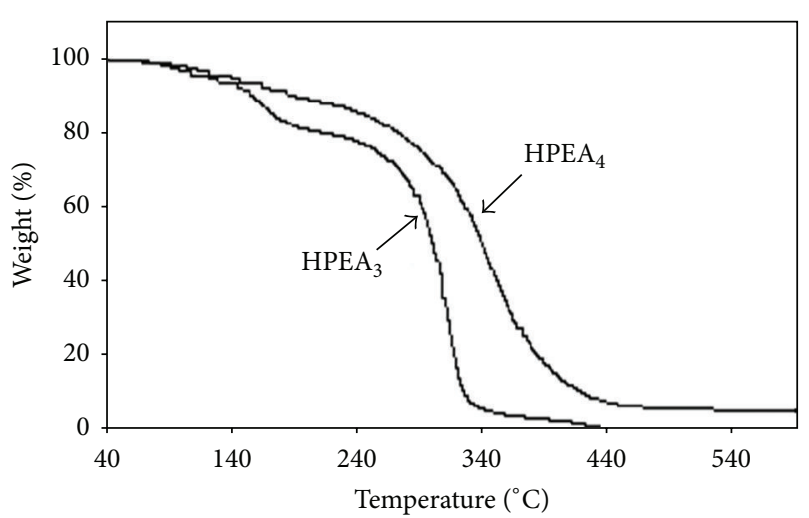

(b)

FIgure 6: TGA of $\mathrm{M}_{7}, \mathrm{M}_{10}, \mathrm{HPEA}_{3}$, and $\mathrm{HPEA}_{4}$.

$\mathrm{M}_{1}$ and $\mathrm{M}_{4}$ nanocomposites up to $440^{\circ} \mathrm{C}$. However, $10 \%$ and $5 \%$ weight loss was recorded for $\mathrm{HPEA}_{1}$ and $\mathrm{HPEA}_{2}$, respectively up to $190^{\circ} \mathrm{C}$, and then sharp decomposition of both samples began at $290^{\circ} \mathrm{C}$. On the other hand, although $\mathrm{M}_{7}$ and $\mathrm{M}_{10}$ nanocomposites lost 20.45 and $14.87 \%$ of their weights approaching $440^{\circ} \mathrm{C}$, and $\mathrm{HPEA}_{3}$ and $\mathrm{HPEA}_{4}$ lost $11.5 \%$ and $7.4 \%$ of their samples weights up to $165^{\circ} \mathrm{C}$, then the loss approaching $18 \%$ for $\mathrm{HPEA}_{3}$ (Figure 6). TG curves of $\mathrm{HPEA}_{3}$ and $\mathrm{HPEA}_{4}$ descended for complete decomposition of samples at $300^{\circ} \mathrm{C}$ and $310^{\circ} \mathrm{C}$, respectively.

The weight loss with respect to $\mathrm{M}_{13}$ and $\mathrm{M}_{16}$ nanocomposites reached $18 \%$ and $10 \%$ of the samples' initial weights approaching the same temperature range $\left(440^{\circ} \mathrm{C}\right)$. Slight weight loss was detected for $\mathrm{HPEA}_{5}$ and $\mathrm{HPEA}_{6}$ till $180^{\circ} \mathrm{C}$ (i.e., $6 \% \mathrm{HPEA}_{5}$ and $3 \% \mathrm{HPEA}_{6}$ ) (Figure 7). Both samples began their final degradation at $280-340^{\circ} \mathrm{C}$.

From the previous results, the diethanolamine-based hyperbranched polymers and their nanocomposites demonstrated less thermal stability than that of the diisopropanolamine-based ones. That was strongly ascribed to the larger number of carboxyl groups in the first DEAbased hyperbranched polymers more than that in the second DIPA-based ones which probably reacted with alcohol groups to from easily evaporated water molecules.
DSC measurements indicated obvious changes in $T_{g}\left({ }^{\circ} \mathrm{C}\right)$ values of $M_{1}, M_{4}, M_{7}, M_{10}, M_{13}$, and $M_{16}$ nanocomposites with respect to their pristine hyperbranched polymers HPEA $_{1-6}$, where the $T_{g}$ values transformed from $-24,30$, $-32,-14,-19$, and $42^{\circ} \mathrm{C}$ for $\mathrm{HPEA}_{1,2,3,4,5,6}$ parents hyperbranched polymers to $81,187.7,63.6,75,74.7$, and $188^{\circ} \mathrm{C}$ for $M_{1}, M_{4}, M_{7}, M_{10}, M_{13}$, and $M_{16}$ nanocomposites. Therefore, compared to the parent hyperbranched polymers, the nanocomposites demonstrated higher thermal stability referring to the influence of clay.

The morphology of the resulting nanocomposites was studied via TEM (Figure 8). Irregular ordering of clay platelets including areas of destructed ones revealing intercalation to semiexfoliation structure. However, in case of $M_{16}$, complete regions of destructed clay platelets appeared led to exfoliation behavior.

\section{Conclusion}

Polyesteramide-hyperbranched polymers successfully formed nanocomposites with untreated montomorillonite clay (MMT) relying on their high number of polar end groups. Three percent of clay were used such as $(4,10$, 


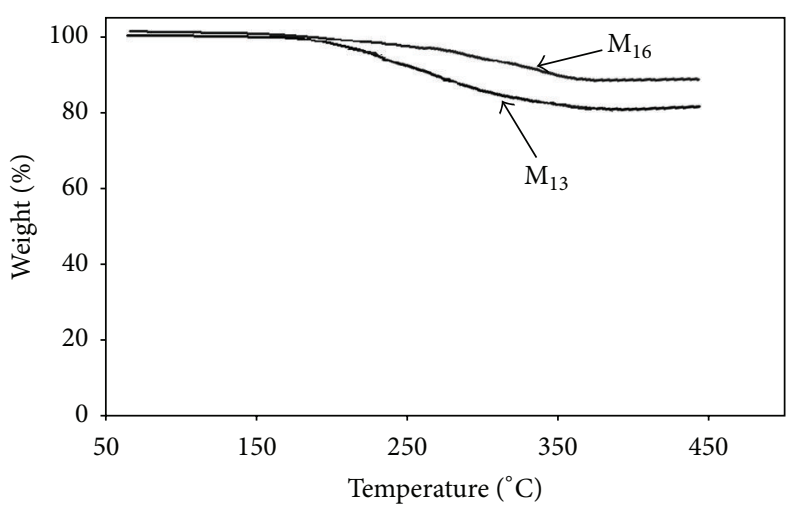

(a)

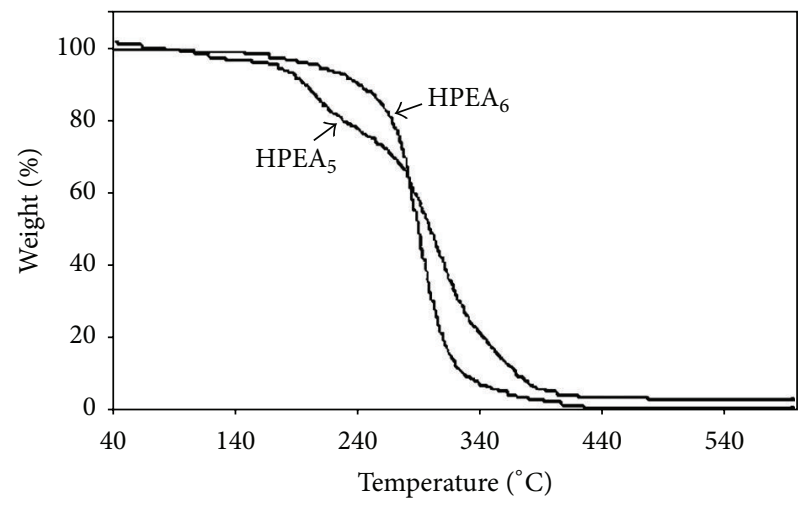

(b)

Figure 7: TGA of $\mathrm{M}_{13}, \mathrm{M}_{16}, \mathrm{HPEA}_{5}$, and HPEA 6 .

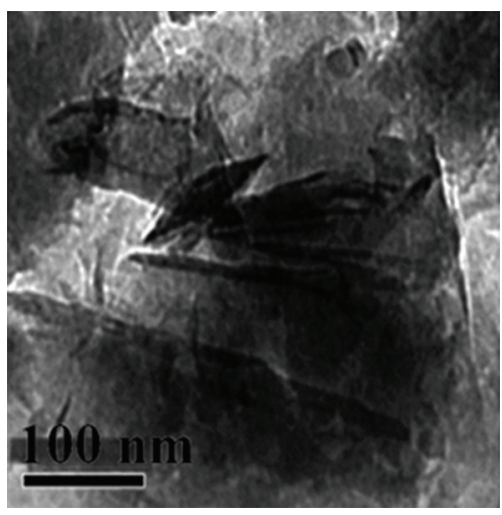

$\left(\mathrm{M}_{1}\right)$

(a)

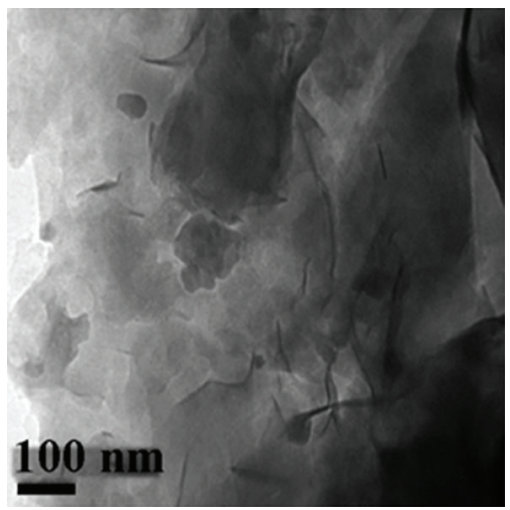

$\left(\mathrm{M}_{10}\right)$

(d)

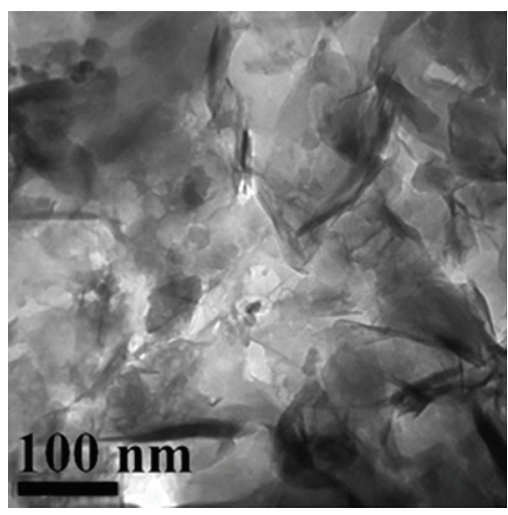

$\left(\mathrm{M}_{4}\right)$

(b)

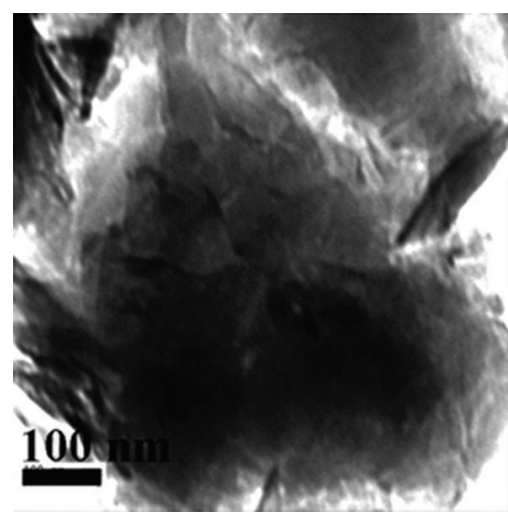

$\left(\mathrm{M}_{13}\right)$

(e)

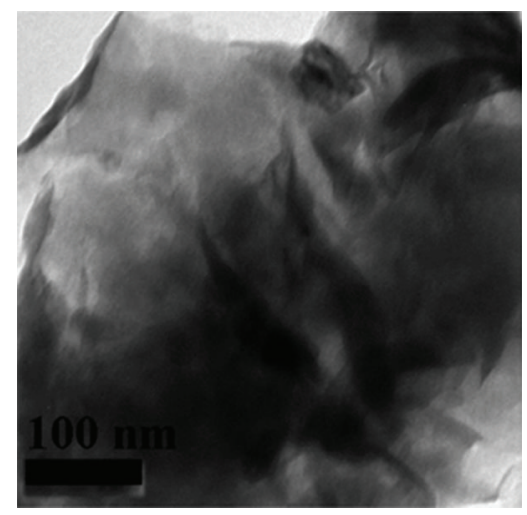

$\left(\mathrm{M}_{7}\right)$

(c)

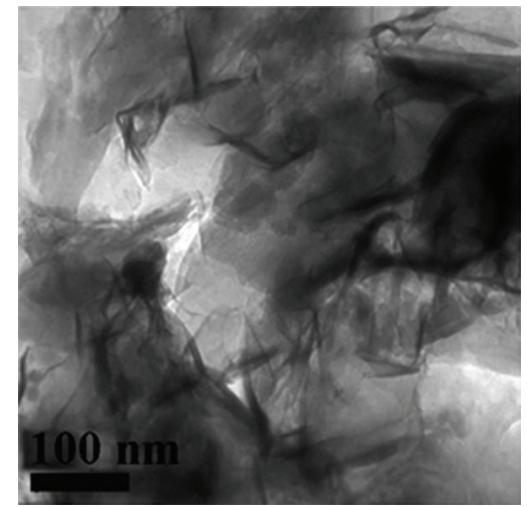

$\left(\mathrm{M}_{16}\right)$

(f)

FIgURE 8: TEM of HEPA at 4\% MMT.

$15 \mathrm{wt} \%)$. However, the low loading content of clay (4\%) presented obvious higher displacement of the clay layers than other percents and caused intercalated nanocomposites with the hyperbranched polymers in most cases. Phthalic anhydride-based hyperbranched polymers with DIPA showed exfoliated morphology for its nanocomposite at $4 \%$ clay. Also, referring to the thermal studies (TGA and DSC data), it was elucidated that the nanocomposites based on the hyperbranched polymers derived from the reaction of the anhydrides and DEA $\left(M_{1}, M_{7}\right.$, and $\left.M_{13}\right)$ were less thermally 
TABLE 1: Formation of HPEA $_{1-6} /$ clay nanocomposites at different clay (MMT) percent.

\begin{tabular}{|c|c|c|}
\hline Entry & Conditions & $\begin{array}{c}d(\mathrm{XRD}) \\
\mathrm{nm}\end{array}$ \\
\hline $\mathrm{M}_{1}$ & $\mathrm{HPEA}_{1}-\mathrm{MMT}(4 \%)$ & 1.935 \\
\hline $\mathrm{M}_{2}$ & $\mathrm{HPEA}_{1}-\mathrm{MMT}(10 \%)$ & 1.879 \\
\hline $\mathrm{M}_{3}$ & HPEA $_{1}-\mathrm{MMT}(15 \%)$ & 1.850 \\
\hline $\mathrm{M}_{4}$ & $\mathrm{HPEA}_{2}-\mathrm{MMT}$ (4\%) & 2.143 \\
\hline $\mathrm{M}_{5}$ & $\mathrm{HPEA}_{2}-\mathrm{MMT}(10 \%)$ & 1.913 \\
\hline $\mathrm{M}_{6}$ & $\mathrm{HPEA}_{2}-\mathrm{MMT}(15 \%)$ & 1.531 \\
\hline $\mathrm{M}_{7}$ & $\mathrm{HPEA}_{3}-\mathrm{MMT}(4 \%)$ & 1.384 \\
\hline $\mathrm{M}_{8}$ & $\mathrm{HPEA}_{3}-\mathrm{MMT}(10 \%)$ & 1.372 \\
\hline $\mathrm{M}_{9}$ & $\mathrm{HPEA}_{3}-\mathrm{MMT}(15 \%)$ & 1.344 \\
\hline $\mathrm{M}_{10}$ & $\mathrm{HPEA}_{4}$-MMT (4\%) & 1.856 \\
\hline $\mathrm{M}_{11}$ & $\mathrm{HPEA}_{4}-\mathrm{MMT}(10 \%)$ & 1.731 \\
\hline $\mathrm{M}_{12}$ & $\mathrm{HPEA}_{4}-\mathrm{MMT}(15 \%)$ & 1.661 \\
\hline $\mathrm{M}_{13}$ & $\mathrm{HPEA}_{5}-\mathrm{MMT}(4 \%)$ & 1.865 \\
\hline $\mathrm{M}_{14}$ & $\mathrm{HPEA}_{5}-\mathrm{MMT}(10 \%)$ & 1.857 \\
\hline $\mathrm{M}_{15}$ & HPEA $_{5}-\mathrm{MMT}(15 \%)$ & 1.846 \\
\hline $\mathrm{M}_{16}$ & $\mathrm{HPEA}_{6}-\mathrm{MMT}(4 \%)$ & Exfoliation \\
\hline $\mathrm{M}_{17}$ & $\mathrm{HPEA}_{6}-\mathrm{MMT}(10 \%)$ & 1.850 \\
\hline $\mathrm{M}_{18}$ & $\mathrm{HPEA}_{6}-\mathrm{MMT}(15 \%)$ & 1.840 \\
\hline
\end{tabular}

HPEA $_{1,3,5}$ are DEA-based hyperbranched polymers.

$\mathrm{HPEA}_{2,4,6}$ are DIPA-based hyperbranched polymers.

stable than that resulted from DIPA-based ones $\left(M_{4}, M_{10}\right.$, and $\left.\mathrm{M}_{16}\right)$. Generally, hyperbranched polyesteramides/MMT nanocomposites displayed higher thermal stability than the original hyperbranched polymers. TEM confirmed the intercalated morphology in almost all cases.

\section{References}

[1] A. Chafidz, I. Ali, M. E. A. Mohsin, R. Elleithy, and S. AlZahrani, "Nanoindentation and dynamic mechanical properties of PP/clay nanocomposites," Journal of Polymer Research, vol. 19, article 9906, 2012.

[2] N. Greesh, P. C. Hartmann, and R. D. Sanderson, "The effect of clay loading on the morphology and properties of poly(styrene-co-butyl acrylate)/clay nanocomposites," Macromolecular Materials and Engineering, vol. 294, no. 3, pp. 206212, 2009.

[3] N. Bitinis, M. Hernandez, R. Verdejo, J. M. Kenny, and M. A. Lopez-Manchado, "Recent advances in clay/polymer nanocomposites," Advanced Materials, vol. 23, no. 44, pp. 5229-5236, 2011.

[4] S. K. Nayak and S. Mohanty, "Dynamic mechanical, rheological, and thermal properties of intercalated polystyrene/organomontmorillonite nanocomposites: effect of clay modification on the mechanical and morphological behaviors," Journal of Applied Polymer Science, vol. 112, no. 2, pp. 778-787, 2009.

[5] A. Akbari, S. Talebanfard, and A. Hassan, "The effect of the structure of clay and clay modifier on polystyrene-clay nanocomposite morphology: a review," Polymer-Plastics Technology and Engineering, vol. 49, no. 14, pp. 1433-1444, 2010.
[6] E. Pavlacky, N. Ravindran, and D. C. Webster, "Novel in situ synthesis in the preparation of ultraviolet-curable nanocomposite barrier coatings," Journal of Applied Polymer Science, vol. 125, pp. 3836-3848, 2012.

[7] M. Ataeefard and S. Moradian, "Polypropylene/organoclay nanocomposites: effects of clay content on properties," Polymer-Plastics Technology and Engineering, vol. 50, no. 7, pp. 732-739, 2011.

[8] P. Kiliaris and C. D. Papaspyrides, "Polymer/layered silicate (clay) nanocomposites: an overview of flame retardancy," Progress in Polymer Science, vol. 35, no. 7, pp. 902-958, 2010.

[9] I.-K. Yang and P.-H. Tsai, "Intercalation and viscoelasticity of poly(ether-block-amide) copolymer/montmorillonite nanocomposites: effect of surfactant," Polymer, vol. 47, no. 14, pp. 5131-5140, 2006.

[10] R. Wilson, T. S. Plivelic, A. S. Aprem, C. Ranganathaiagh, S. A. Kumar, and S. Thomas, "Preparation and characterization of EVA/clay nanocomposites with improved barrier performance," Journal of Applied Polymer Science, vol. 123, no. 6, pp. 3806-3818, 2012.

[11] Y. Turhan, M. Dogan, and M. Alkan, "Characterization and some properties of poly(vinyl chloride)/sepiolite nanocomposites," Advances in Polymer Technology, vol. 32, supplement 1, pp. E65-E82, 2013.

[12] S. Akhlaghi, M. Kalaee, E. Jowdar et al., "Simultaneous study of cure kinetics and rheology of montmorillonite/vinyl ester resin nanocomposites," Polymers for Advanced Technologies, vol. 23, no. 3, pp. 534-544, 2012.

[13] C. Shan, Z. Gu, L. Wang et al., "Preparation, characterization, and application of NR/SBR/organoclay nanocomposites in the tire industry," Journal of Applied Polymer Science, vol. 119, no. 2, pp. 1185-1194, 2011.

[14] T. V. Duncan, "Applications of nanotechnology in food packaging and food safety: barrier materials, antimicrobials and sensors," Journal of Colloid and Interface Science, vol. 363, no. 1, pp. 1-24, 2011.

[15] R. Nigmatullin, F. Gao, and V. Konovalova, "Polymer-layered silicate nanocomposites in the design of antimicrobial materials," Journal of Materials Science, vol. 43, no. 17, pp. 5728-5733, 2008.

[16] N. Ghaemi, S. S. Madaeni, A. Alizadeh, H. Rajabi, and P. Daraei, "Preparation, characterization and performance of polyethersulfone/organically modified montmorillonite nanocomposite membranes in removal of pesticides," Journal of Membrane Science, vol. 382, no. 1-2, pp. 135-147, 2011.

[17] M. G. Hosseini, M. Jafari, and R. Najjar, "Effect of polyanilinemontmorillonite nanocomposite powders addition on corrosion performance of epoxy coatings on Al 5000," Surface and Coatings Technology, vol. 206, no. 2-3, pp. 280-286, 2011.

[18] A. A. Sapalidis, F. K. Katsaros, T. A. Steriotis, and N. K. Kanellopoulos, "Properties of poly(vinyl alcohol)-bentonite clay nanocomposite films in relation to polymer-clay interactions," Journal of Applied Polymer Science, vol. 123, no. 3, pp. 1812-1821, 2012.

[19] Y. Xu, Q. Chen, W. Bai, and J. Lin, "Preparation and properties of raw lacquer/multihydroxyl polyacrylate/organophilic montmorillonite nanocomposites," Polymer Bulletin, vol. 68, no. 4, pp. 983-992, 2012.

[20] S. P. Vasilakos and P. A. Tarantili, "Mechanical properties and nanostructure correlation of condensation-type poly(dimethyl siloxane)/layered silicate hybrids," Journal of Applied Polymer Science, vol. 125, no. 1, pp. E548-E560, 2012. 
[21] X. Xia, J. Yih, N. A. D'Souza, and Z. Hu, “Swelling and mechanical behavior of poly ( $\mathrm{N}$-isopropylacrylamide)/Namontmorillonite layered silicates composite gels," Polymer, vol. 44, no. 11, pp. 3389-3393, 2003.

[22] K. Chrissopoulou and S. H. Anastasiadis, "Polyolefin/layered silicate nanocomposites with functional compatibilizers," European Polymer Journal, vol. 47, no. 4, pp. 600-613, 2011.

[23] A. Sharif-Pakdaman, J. Morshedian, and Y. Jahani, "Influence of the silane grafting of polyethylene on the morphology, barrier, thermal, and rheological properties of high-density polyethylene/organoclay nanocomposites," Journal of Applied Polymer Science, vol. 125, no. 1, pp. E305-E313, 2012.

[24] I. Larraza, C. Peinado, C. Abrusci, F. Catalina, and T. Corrales, "Hyperbranched polymers as clay surface modifiers for UVcured nanocomposites with antimicrobial activity," Journal of Photochemistry and Photobiology A, vol. 224, no. 1, pp. 46-54, 2011.

[25] H. Salehi-Mobarakeh, A. Yadegari, F. Khakzad-Esfahlan, and A. Mahdavian, "Modifying montmorillonite clay via silane grafting and interfacial polycondensation for melt compounding of nylon-66 nanocomposite," Journal of Applied Polymer Science, vol. 124, no. 2, pp. 1501-1510, 2012.

[26] C. J. G. Plummer, L. Garamszegi, Y. Leterrier, M. Rodlert, and J.-A. E. Månson, "Hyperbranched polymer layered silicate nanocomposites," Chemistry of Materials, vol.14, no. 2, pp. 486488, 2002.

[27] A. Amin, A. S. Taha, and M. A. A. Abd El-Ghaffar, "Aliphatic polyamidoamine hyperbranched polymers/layered silicate nanocomposites," Journal of Applied Polymer Science, vol. 118, no. 1, pp. 525-537, 2010.

[28] D. Muscat and R. A. T. M. van Benthem, "Hyperbranched polyesteramides-new dendritic polymers," Topics in Current Chemistry, vol. 212, pp. 41-80, 2001.

[29] P. Froehling, "Development of DSM's hybrane hyperbranched polyesteramides," Journal of Polymer Science Part A, vol. 42, no. 13, pp. 3110-3115, 2004.

[30] R. van Benthem, J. Rietberg, and D. Stanssens, "Condensation polymer containing hydroxyalkylamide groups," European Patent, 1036106B1, September 2000.

[31] M. Nahmany and A. Melman, "Chemoselectivity in reactions of esterification," Organic and Biomolecular Chemistry, vol. 2, no. 11, pp. 1563-1572, 2004.

[32] S. M. Burkinshaw, P. E. Froehling, and M. Mignanelli, "The effect of hyperbranched polymers on the dyeing of polypropylene fibres," Dyes and Pigments, vol. 53, no. 3, pp. 229-235, 2002.

[33] R. A. T. M. van Benthem, N. Meijerink, E. Geladé et al., "Synthesis and characterization of bis(2-hydroxypropyl)amidebased hyperbranched polyesteramides," Macromolecules, vol. 34, no. 11, pp. 3559-3566, 2001.

[34] A. Amin, H. H. M. Darweesh, A. M. Ramadan, S. M. M. Morsi, and M. M. H. Ayoub, "Employing of some hyperbranched polyesteramides as new polymeric admixtures for cement," Journal of Applied Polymer Science, vol. 121, no. 1, pp. 309-320, 2011.

[35] A. Amin, H. H. M. Darweesh, S. M. M. Morsi, and M. M. H. Ayoub, "Effect of phthalic anhydride-based hyperbranched polyesteramide on cement characteristics," Journal of Applied Polymer Science, vol. 120, no. 5, pp. 3054-3064, 2011.

[36] A. Amin, H. M. Darweesh, A. M. Ramadan, S. M. M. Morsi, and M. M. H. Ayoub, "Modification of cement with succinic anhydride-based hyperbranched polyesteramide," Journal of Applied Polymer Science, vol. 124, no. 2, pp. 1483-1489, 2012. 

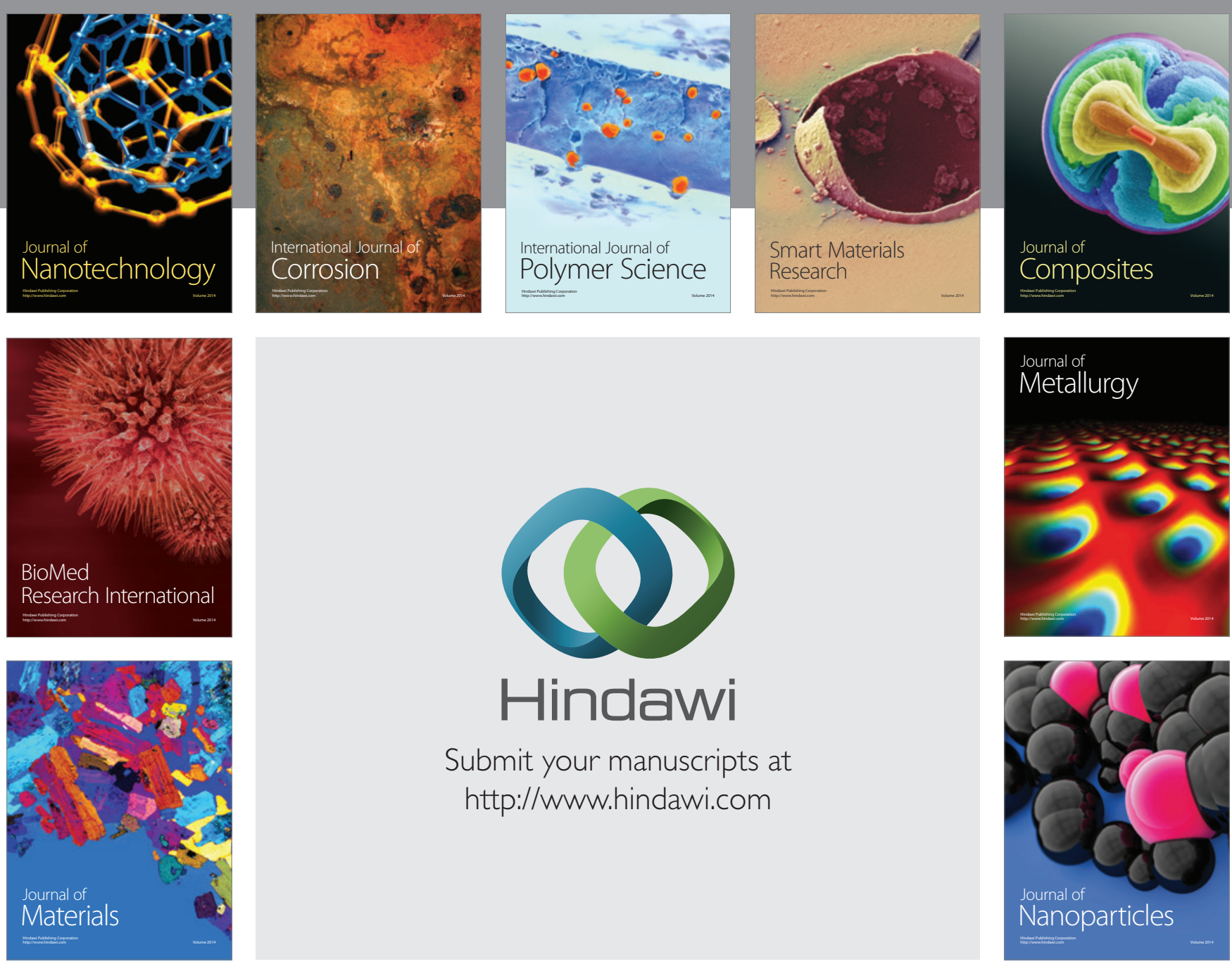

Submit your manuscripts at http://www.hindawi.com
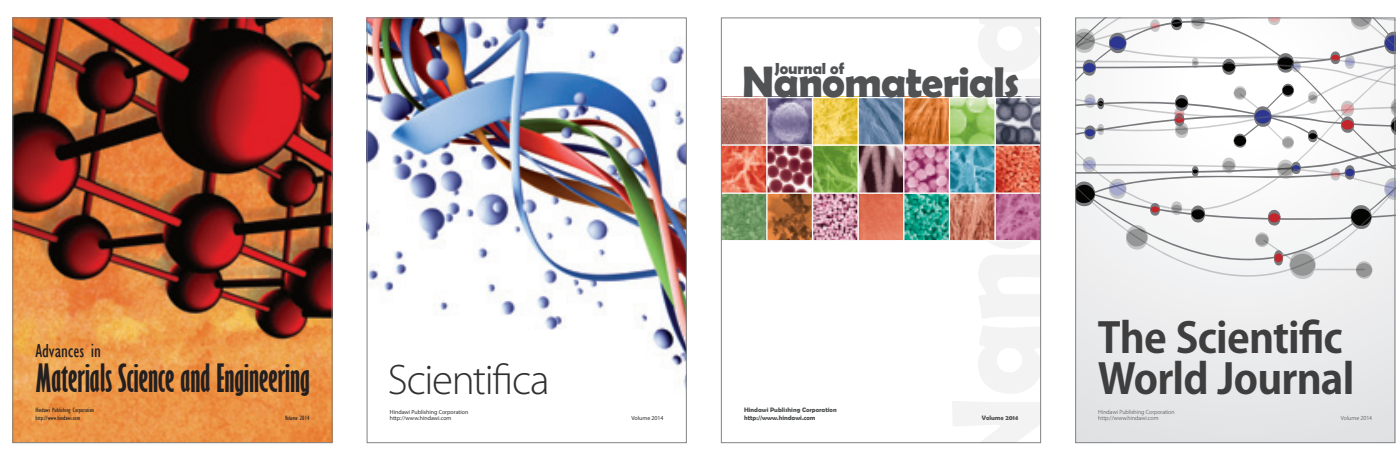

\section{The Scientific World Journal}
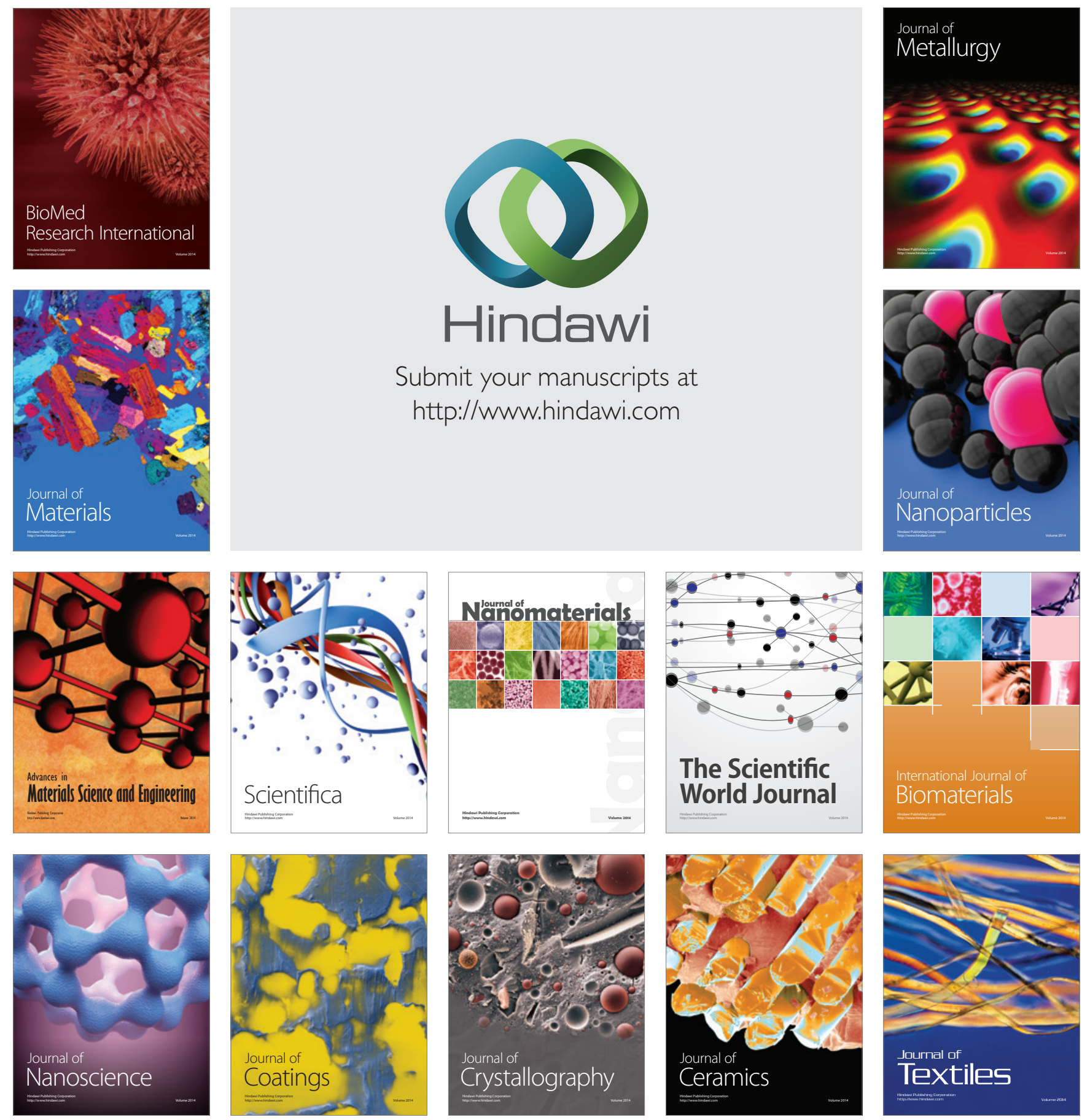